Meta

Journal des tradlucteurs

Translators' Journal

\title{
Translation, Translation Teaching, and the Transfer of Technology
}

\section{Brian Harris}

Volume 28, numéro 1, mars 1983

La traduction dans le monde

Translation around the World

URI : https://id.erudit.org/iderudit/003035ar

DOI : https://doi.org/10.7202/003035ar

Aller au sommaire du numéro

Éditeur(s)

Les Presses de l'Université de Montréal

ISSN

0026-0452 (imprimé)

1492-1421 (numérique)

Découvrir la revue

Citer cet article

Harris, B. (1983). Translation, Translation Teaching, and the Transfer of

Technology. Meta, 28(1), 5-16. https://doi.org/10.7202/003035ar d'utilisation que vous pouvez consulter en ligne.

https://apropos.erudit.org/fr/usagers/politique-dutilisation/ 


\section{TRANSLATION, TRANSLATION TEACHING, AND THE TRANSFER OF TECHNOLOGY*}

Brian HARris

From translation all Science had its offspring.

Giordano Bruno, translated by Florio ${ }^{1}$

It would be a good thing to have one world language, provided it were English.

Attributed to Winston Churchill

In the context of developing countries and the "North-South dialogue", the recently coined term "transfer of technology" 2 comes to mean the implantation of relatively advanced technology from the developed countries into those of the Third World.

Of course this process entails problems of language; and despite the use of word-of-mouth instruction or visual aids, a great deal of the language used is in the form of written texts, ranging from research reports for scientists and high officials, down through manuals for technicians, to educational pamphlets for grass-roots workers and even housewives (e.g. nutritional or birth-control information) and children (especially their school textbooks). When the language of the "sending" countries is not that of the "receiving" ones, then a mass of documentation - amounting sometimes to millions of words for a single project - has to be translated, or else the transfer would be seriously impeded.

Some of this translation is done in the sending countries, typically by government overseas aid agencies or by astute manufacturers anxious to open up new markets. But sometimes the senders are loath to do it, either through lack of motivation - maybe the potential market is small - or because they are less anxious to provide the new technology than the receivers are to obtain

* The research on which this paper is based was funded by the Canadian International Development Agency SEAMEO Regional Language Centre and the University of Ottawa.

1. Quoted in G. Steiner (1975) : After Babel, Oxford University Press, p. 248. Bruno was probably alluding, among other things, to the late medieval translations of philosophy and science from a then more advanced Arabic civilization into the Latin of a Europe emerging from its Dark Ages. See T. Savory (1968): The Art of Translation, revised edition, London, Cape, p. 38. Compare also L.G. Kelly (1979) : The True Interpreter: A History of Translation Theory in the West, Oxford, Blackwell, "Western Europe owes its civilization to translators."

2. On 'technology transfer' or 'technological transfer' : compare la Propriété industrielle et le droit d'auteur, Bulletin de terminologie $\mathrm{n}^{\circ} 149$, Ottawa, Secretary of State Department Translation Bureau, 1973, p. 79 ("technology transfer patent") and 81 ("transfer of technology") and T.R. de Gregori \& O. Pi-Sunyar (1969): Economic Development, the Cultural Context, New York, Wiley, p. 44 ("The Ecology of Technological Transfer"). The concept and its lexicalization in various languages apparently became current in the late 1960's : see Bibliographie, Documentation, Terminologie (UNESCO, Paris) 7:2, March 1967: "Transfert technologique... l'application de connaissances techniques à un secteur (technique ou géographique) autre que celui où elles ont été acquises." 
it; or because the senders, though willing, are really ill-equipped to do the translating, for lack of qualified translators in their own countries who know the receivers' languages.

Actually the language problems and the need for translation are only a little less serious in technology exchanges between developed countries. Since World War II, there has been a kind of superiority complex in the English-speaking countries about their language being so much the dominant one in science and technology that it is up to other peoples to learn it if they want to develop ${ }^{3}$. It is indeed true that something like $60 \%$ of all the world's technical documentation is produced in English : even French, German and Russian scientists often publish papers first in it instead of in their own languages ${ }^{4}$. Nevertheless it follows that some $40 \%$ is not, but is written in German, Japanese, French, Russian, etc. Less than $10 \%$ of this $40 \%$ is ever translated into English; and to make matters worse, the delay in translation ranges from a few weeks to many years $^{5}$.

So when the USSR put the first sputnik into orbit, in 1957, Americans were jolted into realizing that they had failed to keep up with Soviet scientific and technical literature, the great mass of which is naturally in Russian ${ }^{6}$. Whereupon the Joint Publications Research Service of the US government was commissioned to translate several Soviet journals "cover to cover", which it still does; the American Mathematical Society began to do likewise in its own field ${ }^{7}$; and the US Air Force intensified efforts to translate technical Russian into English by computer ${ }^{8}$.

3. One of the British pioneers of machine translation, himself a computer engineer, told the present author that there was no point in attempting to apply MT to the translation of French engineering texts, because so little of interest to English-speaking engineers was written in French anyway!

4. See the Bulletin signalétique of the C.N.R.S. (France) or any of the other scientific abstracts journals.

5. Readers who are linguists might reflect on the fact that it took thirty years before even a summary of such a key work as de Saussure's Cours de linguistique générale appeared in English. This was R.S. Wells' article "De Saussure's System of Linguistics" in Word, Aug. 1947. Another seventeen years passed before the first full translation appeared (W. Baskin's, in 1964).

6. "Even the English world, which earlier nursed the complacency that it inherits all the earthly wisdom and therefore has not much to learn from others, started paying due attention to translation especially after the first Russian sputnik, orbited in 1957, jolted it to take cognizance of the fact that the share of English in world science and technology has already dwindled to less than half and is likely to drop further as the underdeveloped world catches up with the developed. Who is not aware that it was largely through translation of Russian science and technology that a laggard USA of 1957 could achieve its present lead in the space race?" - Indian Scientific Translators Association, Information brochure in connection with 2 nd Symposium on The Role of Scientific \& Yechnical Translation in the Development of India, New Delhi, 1976, p. 1 .

7. Compare the paper by A. Tybulewicz (1981): " 30 years of cover-to-cover translation of Soviet journals", IXth World Congress of the F.I.T., Warsaw, May.

8. Actually the American defence organizations began their support before 1957: "In June 1956, the National Science Foundation awarded a substantial grant to Georgetown University for intensive research in translation of scientific materials from Russian into English... A good part of the grant had in fact come from the C.I.A., as did later support for its project". - E.D. Pendergraft (1967) : "Translating languages", in H. Borko (ed.), Automated Language Processing, New York, Wiley, p. 302.

But then about 1959, "The U.S. Air Force during this period added its support to a 'general purpose table lookup machine for the processing of natural language'." Ibid,, p. 295. 
There was a time when $\mathrm{PhD}$ science candidates in North America had to demonstrate reading competence in two foreign languages. The requirement was dropped by many universities. Now they sometimes regret it as Germany, France, Japan and other non-English-speaking countries enter the league of important innovators of 'high technology'. Yet even PhDs cannot be expected to know all the languages they need for adequate current awareness :

It is not at all economical to make every research scientist learn many languages so that he can do his own translation. It would dissipate the time and energy of the research scientist and minimize the chance for him to become an active researcher. ${ }^{9}$

That is why EURATOM, the National Research Council of Canada and many other research organizations maintain busy translation departments. And in a part of the Third World where English is widely spoken by scientists, namely India, the Indian National Scientific Documentation Centre (INSDOC) does likewise :

It is necessary to organize translation activities on a large scale to serve Indian scientists and technologists. Existing facilities are inadequate. ${ }^{10}$

INSDOC's lead has resulted in scientific and technical translation being regarded in that country as an essential part of the task of librarians in research libraries. Two conferences on that theme have been organized: The Language Barrier in Technology Transfer in 1973, and The Role of Scientific and Technical Translation in the Development of India in 1976. An enthusiastic Indian Scientific Translators Association was founded as early as 1962; it publishes JISTA (Journal of the ISTA). Realizing that the translator training offered in the language departments of the universities does not give students an adequate scientific background, INSDOC has been conducting six-month specialization courses in scientific translation since 1965 . Successful students receive a Diploma in Scientific Translation ${ }^{11}$.

Meanwhile it is very important to recognize that in non-English-speaking areas only a very small elite can read English technical documents with ease. Consider the findings of some in-house research done by a large multinational, XEROX Corporation. XEROX discovered that its English documentation, on which it was relying in most countries where it operated, was often understood only with difficulty - even in places like Sweden where English is used extensively. It was also faced with more and more countries legislating that working documents, manuals, labels and instructions on packaging and the like must appear in the local national languages.

Of the 36 countries [where Xerox operates], only 7 have English as their first language. Even within this group there are sufficient differences within the language to cause some misunderstanding. A further 14 countries are obliged to use English

9. S.N. Methis (1961) : "Training of Translators in scientific and technical translation for research libraries in India", Babel, $14: 1.17-21$, p. 17.

10. See A.R. Chakraborty, R. Satanaryana and S. R. Kundu (1979): "Relevance of machine translation to the scientific and research activities in developing countries with special reference to India", Machine Translation (MT) Research, Report no. 2, New Delhi, INSDOC, Dec., p. 1-24.

11. ISTA, op. cit.; Chakraborty et al., op. cit. Nevertheless, conditions in India elsewhere than at INSDOC remain very unsatisfactory: compare M.S. Dandekar (1974): "The present position of scientific translation in India", Babel, $20: 1.10-13$. 
text documentation largely because of economics related to the scale of operation. Within this group the ability to speak English ranges from very high to very low. The remaining 15 countries require that all documentation is translated before it can be used in their field environment ${ }^{12}$.

Canada is one of the countries in the last category : many consumer products throughout Canada must be labelled in French as well as in English; while in the predominantly French-speaking province of Quebec, almost all working documents must now be provided in French ${ }^{13}$.

Even the few who do enjoy a good working knowledge of English in nonEnglish-speaking countries are usually too busy to apply it outside their own immediate fields of interest. Hence most grass-roots farmers, small businessmen, middle-grade managers, technicians, can only receive information from English documentation at second hand if at all - unless, of course, it is translated.

This can be illustrated by the situation in the European Economic Community. The EEC technocrats in Brussels or Luxemburg might well work together quite conveniently in just one language, perhaps English. Yet EEC regulations have to be translated into all seven languages of the Community before they can be promulgated, because they apply not just to an elite but to all citizens of the member countries. In the commercial sector, British exporters used to be notorious for writing everything in English only. Nowadays Common Market regulations, foreign legislation and competition from other exporters who address the customer in his own language have imposed multilingualism on them, and hence fostered translator training programmes in British universities and polytechnics. Indeed the EEC affects new technology at its very inception, since patents registered at one of its members' patent offices may be valid under the European Patent Convention throughout the Community - provided they are made available in French and German as well as English ${ }^{14}$.

Furthermore, to shatter another illusion often cherished by English speakers, it is by no means certain that knowledge of English is continuing to spread in the world. Perhaps the contrary: while there may be gains in some areas, in others English is actually receding. An example of the latter in the developed countries is the province of Quebec in Canada (as mentioned above); and in the Third World, Malaysia, where all higher education is under official notice to switch from using English to using the national language (Bahasa Malaysia) as the medium of instruction. There are other instances of the resurgence of national languages in formerly English-dominated countries.

Thus it is clear that scientists and technologists, even in high-technology English-speaking countries, cannot afford to neglect R \& D literature in the lan-

12. See J.S.G. Elliston, "Computer aided translation, a business viewpoint", in an excellent collection of papers on machine translation edited by B. Snell (1979): Translating and the Computer, Proceedings of a Seminar, London, 14th November, 1978, Amsterdam, North-Holland Publishing, p. 149-158.

13. In accordance with Act 101 passed by the Quebec National Assembly in 1977. Many French Canadians have difficulty reading English.

14. See the paper by V. Lawson (1981): "Patent translation in the future", IX th World Congress of the F.I.T., Warsaw, May; and the earlier article (1978): "Patents, the translation of a social contract", The Incorporated Linguists, $17: 2$. 30-32. 
guages of other high-technology countries. Nor can those countries' exporters ignore the many languages of their clients. Therefore it is even more unrealistic in the developing countries to assume an adequate knowledge of English, and at all levels of technology recipients. To be sure, the elite technocrats and researchers in those developing countries too, should maintain their English (and other high-technology ${ }^{15}$ languages) or else their current awareness is bound to suffer from the delays and the distortions of re-transmission. Meanwhile, however, for the purpose of informing and teaching their subordinates and the grassroots operatives of newly imported technology, translation is the inevitable medium. For instance, Perum Telekomunikasi (Telecommunications Directorate of Indonesia) needed to train its telephone technicians to use and maintain imported equipment for which the manufacturers supplied the manuals in English. The Indonesian instructors knew enough English to understand them, but their trainees did not. Consequently the instructors were obliged to act as ad hoc translators themselves, with varying results. So the organization considered it urgent to set up an in-house translation department and train specialized translators for it locally ${ }^{16}$.

It follows in general that in Third World regions where there is a shortage of well-qualified technical translators - and that includes most of the Third World - the transfer, and above all the diffusion of new technology from an elite to the masses, require the setting up of professional translator training programmes ${ }^{17}$.

In Egypt, for example, there is currently discussion about instituting bilingual public schools to improve communication with the non-Arab world. Indeed Egypt has a long tradition of bilingual education in private colleges and universities for its elite. However, Egypt is also fortunate in having a good supply of translators, and that is partly due to a tradition which goes back to one of the earliest pioneers of the idea that is central to this article. His name was Rifaat Tahtawi. He was sent in 1826 with the first batch of Egyptian students to study in France. Although he had been educated previously as an imam (Muslim religious leader), he became strongly imbued with French science as well as with some French social ideas, notably about the education of women and their freedom to move around in society. When he returned to Egypt, he managed

15. One could justifiably object to my insistence on 'high' technology, because high technology is often unsuited to the needs of developing countries. Rather they need what is called "intermediate technology': "less sophisticated technologies suitable for small-scale operations", (H. Bowan-Jones (1978) : "Technology and the Third World", in The Third World, Problems and Perspectives, ed. A.B. Mountjoy, London, Macmillan, p. 81). They do need high technology too in some fields; but in the end it does not matter what level of technology we are talking about - if it has to be transferred from one language community to another, than translation will be involved.

16. Personal communication from B. S. Poernomo Soebwo, a student at RELC, Singapore, August 1980. This training programme was set up at PUDSIKLIKBANGTEL (Telecommunication Education, Research and Development Centre) in Bandung. The Centre itself began as a development project of the International Telecommunications Union, and has since been handed over to the Indonesian Government.

17. Thus there are two stages in a technology transfer: an initial implantation, in which information is provided to the receiver country and a small group of its citizens trained, followed by a period of diffusion when the technology becomes widely incorporated into the receiver country's usual practices. Translation has a part to play at both stages. 
to persuade its then ruler, Mehmet Ali, that if the latter wanted to introduce French technology and administrative methods widely, it was not enough to send students to France. French textbooks had to be translated into Arabic for use within Egypt, and consequently a body of young Egyptians must be trained as translators. As a result, Tahtawi founded a school-cum-translation bureau called Kulliyet al-Alsun (Faculty of Languages). That was in 1835. Today, despite a chequered subsequent history, it is attached to Ain Shams University in Cairo, has over 1000 students, and teaches - besides the French and Arabic with which Tahtawi founded it - English, Spanish, Italian, German, Russian and Chinese ${ }^{18}$.

Rifaat Tahtawi's career and the school that is his monument provide a pointer for other Third World countries. They nearly all need a better supply of technical translators. However, as a necessary preliminary, the teachers of those new translators must themselves be found and trained - and if possible trained at home, or near home. For like Tahtawi, the present author does not believe it will be enough to send students to the existing translation schools in the developed countries. For one thing, the target languages required are either not taught at all in those countries or else are not taught to the high, up-to-date standards needed for good translation.

Local training of translation teachers is what one Third World institution, the Regional Language Centre (RELC) in Singapore, recently set out to provide for some of the Southeast Asian countries, namely Indonesia, Malaysia, the Philippines, Thailand and Singapore itself. RELC is mainly a graduate institute for the training of language teachers. Like several other institutes in the region (for instance the Mathematics Centre at Penang in Malaysia) it is owned and run cooperatively by a consortium of ministries of education of Southeast Asian countries. This consortium is called the Southeast Asian Ministers of Education Organization (SEAMEO). RELC has proven itself a very dynamic institution, thanks in no small measure to the personality of its director since its foundation, Dr. Tai Yu-lin. The present author was first invited there in 1979 for a conference on bilingualism. Singapore itself is in fact not just bilingual but quadrilingual in English, Chinese, Malay and Tamil, which of course leads to a good deal of translation activity ${ }^{19}$; and the other countries mentioned are all multilingual to some degree.

It so happened that shortly before the symposium, RELC had conceived the idea of a Four-Month Specialized Certificate Course in Translation in Southeast Asia : Problems, Techniques and Procedures. (It will be referred to here for short by its course code : 207.) The intent was to offer it for the first time in the summer and autumn of 1980 . Dr. Tai showed me the draft syllabus and asked for comments. It allotted more time to theoretical coursework than to practical

18. The author of this paper is profoundly grateful to Dean Abd al-Samih Muhammad Ahmad, as well as to the staff and students of al Alsun for the warm welcome they extended to him and especially to Vice-Dean Amin Sami Wassef for the information about the al-Alsun's founder. For details of the syllabus, see Al-Alsun Prospectus, Cairo, Ain Shams University, Faculty of Al-Alsun, 1975, 110 p. (in Arabic).

19. See B. Harris (1979): "Singapore report", Informatio (Bulletin of the Association of Translators and Interpreters of Ontario), $9: 1.1-3$. 
translation exercises. I warned Dr. Tai against this, because years of hard experience have taught our Canadian translation schools - most of which started life, like this RELC course, as ventures by university departments with a heavy bias towards linguistics - how essential it is to accord first place to practical work under teachers who are themselves experienced translators ${ }^{20}$. Dr. Tai accepted the objection, had the syllabus changed accordingly, and put the preparations in the hands of an excellent organizer, a German-Canadian professor with firm ideas about translation teaching, Dr. Franz Eppert of the University of New Brunswick ${ }^{21}$, who was at RELC on a German Federal Republic academic exchange.

In the meantime I was invited back to RELC to teach in the course. It was certainly a delightful prospect because Singapore is such a beautiful city. However there was a financial problem, since RELC could not afford to pay the heavy cost of travel from Canada. So Dr. Tai and I approached the Canadian International Development Agency (CIDA) for a grant. CIDA is the agency of the Canadian government for aid to developing countries. At first CIDA was not very receptive, because it could not see how a grant for a translation course could be classed as development aid; but in the end, thanks to some farsighted intervention by Mr. Michel Dupuy, head of CIDA at that time, and by one of his principal officers, Dr. Michael Oliver, it agreed with the line of argument put forward in this paper. We were perhaps aided by a precedent : CIDA had in fact already given substantial financial assistance to another bilingual country, Mauritius, and sent out Canadian teachers to that Indian Ocean island for three years to help start an institute of bilingualism, the Institut Africain et Mauricien de Bilinguisme, for a group of twelve East African countries ${ }^{22}$. CIDA's more modest agreement in my case was to pay my air fare to Singapore and most of my expenses there, provided my own university would grant me paid leave and RELC supplied me with accomodation. These conditions were met.

Now to describe the syllabus that Dr. Tai and Dr. Eppert worked out ${ }^{23}$. There were some major problems at the outset, beyond those that normally face new translation courses. The students were to be drawn from as many as possible of RELC's sponsoring countries, and in equal numbers from each. In the event this meant that the one syllabus had to cope with five national languages, viz. Mandarin Chinese (Singapore), Bahasa Malaysia (Malaysia and Singapore), Bahasa Indonesia (Indonesia), Pilipino (Philippines) and Thai (Thailand) ${ }^{24}$. The only language everybody could be expected to speak in common was English. So the decision was taken that all the translation taught would be from English

20. See the paper by R. P. Roberts (1981): "Training for the translator of the future", IX th World Congress of the F.I.T., Warsaw, May.

21. See F. Eppert (1977): "Translation and second-language teaching", Canadian Modern Language Review, $34: 1.50-61$.

22. J.R. Kohr personal communication. See also M. Plaice (1980) : "Congrès des sociétés savantes, Association de professeurs de français des universités canadiennes", Meta, $25: 3.379-380$.

23. See Appendix for more details. Mention must also be made of the speedy action taken by Yolande Beh, head librarian of RELC's outstanding applied linguistics library, to acquire a sufficient collection of documents for students' research needs.

24. Bahasa Malaysia, Bahasa Indonesia and Pilipino are the official names of the languages formerly known as Malay, Indonesian and Tagalog respectively. 
into the national languages and not between those languages. This was also a realistic decision because most - though by no means all - of the translation needs of the region at present are for translation from English. It also meant that English could be used as a working language between all students and professors.

Obviously, though, outsiders like myself could not teach the practical translation exercises. So a second major organizational decision was one to divide the four-month programme into three roughly equal periods, with outsiders teaching only the first part and then handing over to instructors from the region. letter ${ }^{25}$.

How did it work out? The following is quoted from RELC's own news-

Phase I focused on both the theoretical and applied aspects of the fascinating phenomenon of translation. Dr. Eppert introduced the course members to aspects and concepts of modern translation theory by critically examining the classification of translation processes and by exploring techniques for assessing translation quality. Following his introduction, Professor Brian Harris offered a course on linguistic problems of translation by applying linguistics to the description of translation and by discussing linguistic concepts, models and terminology that are useful for this purpose. His second course dealt with the professional aspects of translation in the world, the development of professional organizations, pay, levels of competence, accreditation and training. In two seminars Professor Harris focused on Terminology and Computer Aids.

The joint effort of the Goethe-Institut and RELC resulted in a significant contribution by Professor Dr. Wolfram Wilss, Director of the Institute of Translation and Interpreting at the University of Saarbruecken, Federal Republic of Germany, who is one of the foremost authorities in translation theory. Professor Dr. Wilss is especially known for his substantial book The Science of Translation (1977) as well as for his many articles in professional journals. During his week's stay at RELC he discussed with the course members the preconditions, perspectives, limitations of a didactically and methodically appropriate approach to the teaching of translation. In one seminar he gave an illuminating historical overview on the concept of equivalence and outlined the state of the art today. His second seminar had as its topic: Machine Translation, one of his areas of special expertise.

Another cooperative effort between the Summer Institute of Linguistics and RELC enabled Mr. and Mrs. R. Hohulin to spend one month at RELC. The couple from the USA can pride themselves on having had eighteen years of practical translation experience in the Philippines and on being constantly involved with translation teaching and translation projects. Their work has resulted in many very specific yet highly relevant publications, the latest of which is a bilingual dictionary : Keleyi Kallahen - English that will be published soon. This background made Mr. and Mrs. Hohulin ideal lecturers on the problems of bilingual lexicography. Their seminars on the quest for dynamic equivalence, on functional grammar in translation, on translation procedures, on text grammar in translation were always based on the practice in the region, which made their contribution much more relevant to the work of the course members.

One other highlight of Course 207 was a one-week workshop: The Realities of Translation - The Japanese Experience by Mr. Sen Nishiyama, a leading Japanese translation expert. Mr. Nishiyama is the eminent translator of Edwin $\mathrm{O}$ Reischauer's books, well-known interpreter for Japanese Prime Ministers, Ameri-

25. "Visiting specialists and consultants in translation", RELC Newsletter, $13: 3.4-6,1980$. 
can ambassadors and other high ranking officials, and author of several books on interpreting and of numerous treatises on cross-cultural comparision and communication. His informal lectures revealed clearly and convincingly the relevance and value of the Japanese translation experience to current translation developments in Southeast Asia. His visit was made possible through the assistance of the Japanese Government and being the very first occasion, a reception was held as a gesture of appreciation.

From New Zealand came Mr. H.V. George, Director of the English Language Institute, Victoria University of Wellington, who surveyed the role of translation in education and in the acquisition of second languages.

Mr. Alex Brotherton of the Institute Voor Vertaalkunde, Universiteit van Amsterdam on his stop-over from Malaysia was kind enough to offer a seminar on the highly complex topic: Translation-oriented Textual Analysis.

Thus Phase I was the theory and lecture part, and quite a concentrated dose of it at that. The objection may be voiced, "Why start with so much theory and wisdom when practical work has been held to be essential?" Here it is necessary to recall that the objective of Course 207 was to train translation teachers. Therefore there could be no question of recruiting beginners as students. On the contrary, all the students were carefully selected on the basis of their previous experience as working translators ${ }^{26}$. So they already possessed a fairly solid basis from which to discuss theory and appreciate other people's experience.

Phase II of Course 207 started in mid-August with heavy emphasis given to exercises in translation critique and translation exercises totalling seventy-two hours of practice. The course members were divided into country groups and the Ministries of Education of Indonesia, Malaysia, Philippines, Singapore and Thailand nominated special consultants for this extremely important and valuable period of guided practice.

The special consultant from Indonesia was Miss Sunarjati Djajanegara, Senior Lecturer, School of Letters, University of Indonesia, Jakarta, who has had experience in organizing a translation workshop in Indonesia. Malaysia sent Dr. Haji Abdullah Hassan, Co-ordinator of the Language Studies Unit of the Universiti Sains Malaysia, Pulau Pinang.

The Philippines was represented by Dr. Alfonso O Santiago, Professor of Pilipino and Linguistics, Philippine Normal College, Manila, who is the author of a textbook on the art of translating, as well as several other books and many articles.

Singapore's Acting Director of the Chinese Language and Research Centre, National University of Singapore, Mr. Loo Shaw Chang, was responsible for the translation practice from English to Mandarin. He has written numerous articles on the teaching of Mandarin and is active in Chinese-English translation work.

Dr. Pongsri Lekawatana, Associate Professor and Head, Department of English, Faculty of Arts, Chulalongkorn University, Bangkok, was in charge of the Thai group. She is the editor of an anthology on the teaching of translation and has been teaching translation for many years.

During this one-month stay at RELC these special consultants not only provided the practice sessions but also worked out detailed and innovative guidelines for the two substantial course projects to be completed by each course member as a course requirement. The first project called Translation Commentary is a detailed investigation of an existing translation, and the second, Translation Production, is the actual translation of a hitherto untranslated text ${ }^{27}$.

26. See "Admission" in Appendix.

27. RELC Newsletter, loc. cit. 
Here tribute is due to Dr. Eppert's coordinating skills, I confess I was dubious whether the regional consultants, never having met before and coming from different cultures, and being in addition people of mature experience who might be expected to have set ideas of their own, could be expected to direct their students' work and evaluate it just the way RELC wanted it done and all in the same way. However, Dr. Eppert drew up a very good set of guidelines ${ }^{28}$; and then, by discussion in committee with the instructors, he achieved a reasonable degree of consistency.

Phase III left the students to finish their projects on their own; but these were then sent to the regional instructors for marking.

How successful was Course 207? My impression was that, over and above the techniques imparted, there was an important effect on the morale of the 29 students. They were enabled to see themselves as members of a world-wide profession with international standards, and to go home considering how the profession in their own countries should fit into this broader picture.

We did, however, feel strongly the lack of a suitable textbook for such programmes.

I would add that the learning was by no means all one way. For us from the West it was naturally an opportunity to learn about the languages, cultures and working lives of our colleagues and students. In the translation field there is a high level of activity throughout the region, of which we only had the haziest idea beforehand. The profession there too is awakening to the need to organize : Singapore and Indonesia have had their professional associations for several years, and one is now forming in the Philippines ${ }^{29}$. Women are just as numerous in our profession there as they are in Europe or America ${ }^{30}$. And then there is a phenomenon of our time which doubtless exists in the developed countries as well yet is particularly striking in Asia: it is the enormous amount of educational textbook translation which is being done - to the extent that we ought to recognize 'school textbook translator' as a specialized branch of the profession ${ }^{31}$.

One country where the textbook problem is particularly acute is Malaysia, for the reason mentioned earlier. This has led to a rather surprising project, and to yet another example of technology transfer. Dr. Tong Loong Cheong of the School of Mathematical Sciences in the Universiti Sains Malaysia (on Penang Island) has launched a machine translation project with the aid of the Groupe de recherche pour la traduction automatique directed by Prof. Bernard Vauquois at the Université scientifique et médicale de Grenoble, France. Its purpose is

28. Guidelines for Course 207 Projects, Singapore, RELC, Aug. 1980.

29. In Singapore, the Singapore Translators and Interpreters Union (SITU); in Indonesia, Himpunan Penterjemah Indonesia (Association of Indonesian Translators). On the occasion of this congress, the F.I.T. has admitted three Third World national associations to membership, viz. the Nigerian Association of Translators and Interpreters, the Asociación de Traductores Profesionales de México and the Tanzanian Association of Translators. Other countries already represented included Argentina, Brazil, South Korea, Guatemala, Indonesia and Uruguay.

30. While I was at RELC, the Singapore Straits Times reported that the Saudi Arabian government was going to admit women to its civil service for the first time - as translators and clerks!

31. Associated with this field is the enormous project, announced in 1980, to translate the Encyclopedia Britannica into Chinese : 8000000 words in four years. 
to translate English mathematics texts into Bahasa Malaysia by computer. In August 1980, Dr. Cheong and Professor Vauquois organized a National Workshop on Automatic Translation at Penang, at which I saw the sophisticated software from Grenoble operating in USM's well-equipped computer centre ${ }^{32}$.

This event coincided with the news, reported in the Singapore Straits Times, that Japan's Ministry of International Trade and Industry, convinced of the enormous market for machine translation a few years down the road apparently more convinced than the Western countries that pioneered MT was to fund a new five-year programme of MT research to the tune of $150000000 \$ 33$. For this reason among others, a major feature of translation development in Asia in the next decade may well be technology transfers within that continent, and Japanese may come to rival English for its place as dominant source language.

\section{APPENDIX}

RELC 2804A/INFO

\section{SOUTHEAST ASIAN MINISTERS OF EDUCATION ORGANIZATION (SEAMEO) REGIONAL LANGUAGE CENTRE (RELC), SINGAPORE}

Course 207: Four-Month Specialized Advanced Certificate Course in Translation in Southeast Asia : Problems, Techniques, and Procedures

7 July - 1 November 1980

Rationale

1. Translating has become a large-scale activity in this world of ever increasing language contacts. The growing demand for highly skilled translators makes it imperative to thoroughly investigate this activity as well as its results so that ways and means may be found to teach translation effectively. The teaching of translation must be elevated to professional standards comparable to the teaching of second-languages. RELC's unique professional and material resources in this area make an advanced course in translation particularly appropriate.

\section{Admission}

2. Nominees should be selected from those who are likely to become professionally involved in the development of national translation teaching programmes.

3. Candidates should be key personnel or potential key personnel engaged in:

translator training

translation programmes

language teaching programmes requiring translation techniques translation curriculum development

language curriculum development

language teacher training.

Examples of this category would be :

professional translators and translation teachers in governmental institutions persons engaged in the development of bilingual dictionaries persons engaged in the development of instructional materials involving translation university lecturers in translation

in linguistics

in language teaching.

4. For admission as a candidate to the Certificate Course, a person should preferably possess a university degree.

5. The candidate must be proficient in English and must have an excellent command of the national/ official language since the course places heavy emphasis on translations from English into the national/official language(s). The course will be conducted in English.

6. A candidate should have had at least some experience in translation.

32. I also gave a paper entitled "The lessons of METEO", in which I tried to draw some useful advice from Canadian experience in the development of an advanced MT system.

33. This promises to dwarf the $6000000 \$$ so far spent on MT research in Canada. 
7. The candidate should normally be under 45 years of age.

Period and Nature of Study

8. The course will be a four-month intensive programme organized in a 'problem solving' framework with formal instruction kept to a minimum. Each candidate will work on at least $t w o$ major practical projects (See No. 10) to which a considerable amount of course time will be devoted. Candidates from the same country are encouraged to work as a team on these projects; they may, however, work as individuals.

9. The general aim of the course is to study the body of theoretical and practical knowledge that has accrued in the field of translation in order to ensure a critical awareness of the problems, techniques, and procedures involved in translation as a basis for the production of better translations and for the development of better translation teaching programmes in the SEAMEO member countries.

10. The specific aims of the course are :

(a) to introduce course members to aspects and concepts of modern translation theory;

(b) to discuss and possibly solve linguistic problems of translation;

(c) to critically examine proposed basic translation methods and procedures;

(d) to inform course members on the teaching of translation in different parts of the world;

(e) to explore the role of translation in second-language teaching;

(f) to systematically evaluate existing translations;

(g) to independently produce new translations.

11. The course will consist of :

(a) lectures and seminars conducted by RELC staff and invited specialists on topics relevant to the objectives of the course, and

(b) seminars of country sub-groups conducted by translation specialists of SEAMEO member countries.

12. While the selection of project topics is the responsibility of course members after consultation with their educational authorities, topics in the following suggested areas may be considered by the candidates :

Area I: Translation critique

The critical and systematic evaluation of an existing translation from English into the national/official language. (Vice versa is only suggested when the competence in English can be termed "excellent".)

Area II : Translation production

The translation of a hitherto untranslated English text into the national/official language. (Vice versa is only suggested when the competence in English can be termed "excellent".)

Important

13. Texts for (a) the translation critique and

(b) the translation production

should be of reasonable length and by no means exceed 20 pages per project member.

14. Each candidate is expected to bring along several texts

(a) translations plus original text

(b) texts to be translated

both possibly approved by his/her educational authorities.

15. It is also the responsibility of the candidates to bring along all necessary data and materials needed for the proposed two projects (e.g. dictionaries, grammars, background information, special reference material, etc.).

16. The course will be organized into three phases:

Phase I: Emphasis on required courses (Theory and Practice)

(6 weeks)

Phase II : Emphasis on translation critique (Practice) and completion of Project I in consulta(5 weeks) tion with country specialist

Phase III : Emphasis on translation production (Practice) and completion of Project II in con(6 weeks) sultation with country specialist

17. To complete the course a candidate must

(a) satisfy class attendance requirements;

(b) attain a satisfactory standard in required course work; and

(c) complete two course projects of a satisfactory standard.

18. The course will lead to the award of a Certificate. 